\title{
Detection of Ara h 1 (a major peanut allergen) in food using an electrochemical gold nanoparticle-coated screen-printed immunosensor
}

\author{
Rita C. Alves, Filipa B. Pimentel, Henri P.A. Nouws, Raquel C.B. Marques, \\ María Begoña González-García, M. Beatriz P.P. Oliveira, Cristina Delerue-Matos
}

\author{
A B S T R A C T
}

A gold nanoparticle-coated screen-printed carbon electrode was used as the transducer in the development of an electrochemical immunosensor for Ara h 1 (a major peanut allergen) detection in food samples. Gold nanoparticles (average diameter $=32 \mathrm{~nm}$ ) were electrochemically generated on the surface of screen-printed carbon electrodes. Two monoclonal antibodies were used in a sandwich-type immunoassay and the antibody-antigen interaction was electrochemically detected through stripping analysis of enzymatically (using alkaline phosphatase) deposited silver. The total time of the optimized immunoassay was $3 \mathrm{~h} 50 \mathrm{~min}$. The developed immunosensor allowed the quantification of Ara $\mathrm{h}$ 1 between 12.6 and $2000 \mathrm{ng} / \mathrm{ml}$, with a limit of detection of $3.8 \mathrm{ng} / \mathrm{ml}$, and provided precise (RSD $<8.7 \%$ ) and accurate (recovery $>96.6 \%$ ) results. The immunosensor was successfully applied to the analysis of complex food matrices (cookies and chocolate), being able to detect Ara $\mathrm{h} 1$ in samples containing $0.1 \%$ of peanut.

\section{Keywords:}

Electrochemical immunosensor

Biosensor

Screen-printed carbon electrode

Allergen

Peanut

Ara h 1

\section{Introduction}

Food allergies, which affect up to $10 \%$ of the general population (Chafen et al., 2010), have been increasing in industrialized countries, and are a public health problem and a main food safety concern. In general, they are originated by an immunological hypersensitivity, usually against certain food proteins or glycoproteins (antigens). Food-induced allergic reactions are responsible for symptoms that often involve the gastrointestinal tract (diarrhoea, emesis), the respiratory system (asthma, rhinitis), and the skin (atopic dermatitis, urticaria). The more rare anaphylactic reactions are particularly relevant because they are potentially life threatening (Berin and Sicherer, 2011; Leung and Kamat, 2008). Food allergy is usually controlled by allergen avoidance or symptom treatment. Correct and assertive food labelling is particularly relevant in this case, since it will allow consumers to make an informed choice for the implementation of a successful avoidance strategy. However, cross-contamination during food processing or ingredients with "hidden" allergens can largely impair this task.
Therefore, food manufacturers usually include a preventive text on the package ("may contain traces of..."), not only to protect sensitized individuals but also themselves. This, however, reduces the available options for allergic consumers. In this perspective, reliable, accurate, and highly sensitive and selective methods are needed to evaluate, with assurance, if a certain allergen is (or not) present in a foodstuff. The methodologies available for allergens detection can be divided into three main groups: immunoassays for protein detection (Besler et al., 2002; Monaci and Visconti, 2010; Taylor et al., 2009), DNA-based methods (Słowianek and Majak, 2011; Monaci and Visconti, 2010) and mass spectrometry (Monaci and Visconti, 2009). Biosensors have been emerging recently as powerful alternatives to classical methods for the detection and quantification of allergens, but their application in this field is still scarce.

Peanut (Arachis hypogaea) is one of the most allergenic foods. According to the Food Allergen Labelling and Consumer Protection Act of 2004 (FALCPA 2004, Public Law 108-282, Title II) in the United States, and the Directive 2000/13/EC, as amended by Directives 2003/89/EC and 2007/68/EC, within the European Union, the presence of peanut in a food product has to be declared on its label. In North America the incidence of peanut allergies is still increasing, and $\sim 1 \%$ of the population is already affected 
(Chruszcz et al., 2011). This type of allergy persists in $80 \%$ of sensitized individuals, and for many of them contact with even very small amounts of the allergens originates severe reactions (e.g. anaphylaxis) (de Leon et al., 2007; Khodoun et al., 2009). Ara h 1 , a $7 \mathrm{~S}$ vicilin-like globulin, is a seed storage protein and a major peanut allergen. It is thermostable and resistant to digestion in the human gastrointestinal tract and is recognized by serum IgE from more than $90 \%$ of peanut-allergic patients (Chruszcz et al., 2011). Therefore, it is considered a suitable marker to identify the presence of peanut in food products and production lines.

There is a real need for efficient methods able to detect very low amounts of peanut allergens. In a perspective of public health and food safety, we intend to answer the needs of allergic consumers, and to contribute to a more accurate labelling of food products by the food industry. Therefore, the aim of this work was to develop a highly sensitive and selective electrochemical immunosensor able to detect low concentrations of Ara h 1 in food samples.

There are very few publications regarding the development of biosensors for the specific detection of Ara $h$ 1, namely using surface plasmon resonance (SPR) (Pollet et al., 2011; Tran et al., 2013) and electrochemical impedance spectroscopy (EIS) (Huang et al., 2008; Singh et al., 2010; Sun et al., 2012) for detection purposes. Huang et al. (2008), Singh et al. (2010) and Pollet et al. (2011) used immunoassays whereas Sun et al. (2012) and Tran et al. (2013) used DNA-based recognition elements.

To the best of our knowledge, in this work, the first voltammetric immunosensor for the detection of Ara $\mathrm{h} 1$ is proposed. An immunosensor based on a screen-printed carbon electrode (SPCE) coated with gold nanoparticles was developed, validated, and used to detect the protein in real food samples. The gold nanoparticles were generated directly on the working electrode of the SPCE through electrochemical deposition of ionic gold. The immunosensing strategy was based on a sandwich format in which two monoclonal mouse IgG antibodies against Ara $\mathrm{h} 1$ were used as capture and detection antibodies. The detection antibody used in this work was labelled with alkaline phosphatase and the electrochemical detection relied on an enzyme-catalyzed metal precipitation followed by applying an anodic (stripping) voltammetric potential scan (Fanjul-Bolado et al., 2007).

\section{Materials and methods}

\subsection{Instrumentation}

The electrochemical deposition of the gold nanoparticles and linear sweep voltammetric analysis were performed using an Autolab PGSTAT12 potentiostat-galvanostat from Metrohm Autolab controlled by GPES4.9 software.

Disposable screen-printed carbon electrodes (SPCEs, DRP-110) were purchased from DropSens. These electrodes incorporate a conventional three-electrode configuration, printed on ceramic substrates $\left(3.4 \times 1.0 \mathrm{~cm}^{2}\right)$. The working electrode (a $4-\mathrm{mm}$ diameter circle) and the counter electrode were both made of carbon inks, while the pseudoreference electrode and the electric contacts were composed of silver. A ring-shaped layer printed around the working electrode constitutes the reservoir $(50 \mu \mathrm{l})$ of the electrochemical cell. The SPCEs were connected to the potentiostat through a specific connector (DRP-CAC) from DropSens.

For sample preparation a mill (GM 200, RETSCH) and two centrifuges (Labofuge Ae, Heraeus Sepatech and Heraeus Fresco 17 Centrifuge, Thermo Fisher Scientific) were used.

SEM images were obtained at the "Centro de Materiais da Universidade do Porto (CEMUP)" using FEI QUANTA 400 FEG/EDAX Pegasus X4M equipment.

\subsection{Reagents}

Tris(hydroxymethyl)aminomethane (Tris, $\geq 99.8 \%$ ), magnesium nitrate hexahydrate (99\%), hydrochloric acid (37\%), nitric acid ( $\geq 65 \%$ ), $\beta$-casein from bovine milk ( $\geq 98 \%$ ), 3-indoxyl phosphate (3-IP, $\geq 98 \%$ ), streptavidin-alkaline phosphatase (SAP) from Streptomyces avidinii, and sodium chloride were all obtained from Sigma-Aldrich. Silver nitrate ( $\geq 99.9995 \%)$ was purchased from Alfa Aesar. Mouse monoclonal anti-Ara h 1 IgG1 (clone 2C12 A11 A3) antibody (capture antibody), biotinylated monoclonal anti-Ara h 1 IgG1 (clone 2F7 C12 D10) antibody (detection antibody) and purified Ara $\mathrm{h} 1$ were obtained from Indoor Biotechnologies. Throughout the work ultra-pure water (resistivity $=18.2 \mathrm{M} \Omega \mathrm{cm}$ ) was used and was obtained from a Millipore (Simplicity 185) water purification system. The tetrachloroauric(III) acid solution $\left(1 \times 10^{-4} \mathrm{M}\right)$ for the electrodeposition of gold nanoparticles was prepared in $0.1 \mathrm{M} \mathrm{HCl}$. Working solutions of the antibodies, Ara h 1 protein, and S-AP $\left(2 \times 10^{-10} \mathrm{M}\right)$ were prepared in a $0.1 \mathrm{M}$ Tris- $\mathrm{HNO}_{3} \mathrm{pH} 7.2$ buffer. The solution containing 3-IP $\left(1.0 \times 10^{-3} \mathrm{M}\right)$ and silver nitrate $\left(4.0 \times 10^{-4} \mathrm{M}\right)$ was prepared daily in a $0.1 \mathrm{M}$ Tris- $\mathrm{HNO}_{3} \mathrm{pH} 9.8$ buffer containing $\mathrm{Mg}\left(\mathrm{NO}_{3}\right)_{2}\left(2 \times 10^{-2} \mathrm{M}\right)$, and was stored at $4{ }^{\circ} \mathrm{C}$ and protected from light before use.

\subsection{Samples and sample preparation}

To evaluate the immunosensor's performance different types of food samples, bought in local supermarkets, were used: peanut, cookies, milk chocolate, chocolate with peanut, cashews, almonds, walnuts, pistachios, peas, lentils, and lupines. The cookies were composed of a complex matrix containing wheat flour, saccharose, vegetable oil, vitamin E, glucose, fructose, whey powder, salt, sunflower lecithin, sodium bicarbonate, caramel, sodium metabisulphite, and egg. In addition, samples containing increasing amounts of peanut $(0.1 \%$; $0.3 \%$; and $1.5 \%)$ were prepared in the cookie matrix.

Samples were prepared according to previously described procedures (Pele et al., 2007; Pollet et al., 2011) with minor modifications. Briefly, after homogenization in a mill at $10,000 \mathrm{rpm}$ during $20 \mathrm{~s}(3 \times), 1 \mathrm{~g}$ of sample was extracted with $10 \mathrm{ml}$ of Tris- $\mathrm{HNO}_{3}$ buffer $(\mathrm{pH} 8.2,1 \% \mathrm{NaCl})$ at $60{ }^{\circ} \mathrm{C}$ during $30 \mathrm{~min}$. In the particular case of chocolate samples, they were frozen at $-20{ }^{\circ} \mathrm{C}$ before homogenization, and $1 \mathrm{~g}$ of skimmed milk powder (Nestlé) was added before extraction to bind the high amount of phenolic compounds (e.g. tannins) present in this matrix. This procedure was adopted because these compounds have the ability to block the allergens and/or bind to the antibodies. Subsequently, samples were subjected to a first centrifugation step (5000 rpm) during $5 \mathrm{~min}$ (Labofuge Ae, Heraeus Sepatech). An aliquot (1 ml) of the supernatant was further centrifuged $\left(4^{\circ} \mathrm{C}\right)$ at $10,000 \mathrm{rpm}$ for 3 min (Heraeus Fresco 17 Centrifuge, Thermo Fisher Scientific) and the resulting supernatant was used directly to perform the immunoassays. Dilutions of the final extracts with $0.1 \mathrm{M}$ Tris- $\mathrm{HNO}_{3} \mathrm{pH} 7.2$ buffer were made when necessary.

\subsection{Sensor fabrication}

\subsubsection{Electrode surface modification with gold nanoparticles}

Surface nanostructuration of the SPCEs was based on a previously described procedure (Martínez-Paredes et al., 2009a, 2009b). The SPCEs were first rinsed with ultrapure water and dried. Then, $40 \mu \mathrm{l}$ of the acidic $1 \times 10^{-4} \mathrm{M}\left[\mathrm{AuCl}_{4}\right]^{-}$solution were placed on the electrode surface. In situ electrochemical deposition of the gold nanoparticles was performed by applying a constant current intensity of $-100 \mu \mathrm{A}$ for $240 \mathrm{~s}$. This was followed by the application of a potential of $0.1 \mathrm{~V}$ during $120 \mathrm{~s}$ to desorb the 

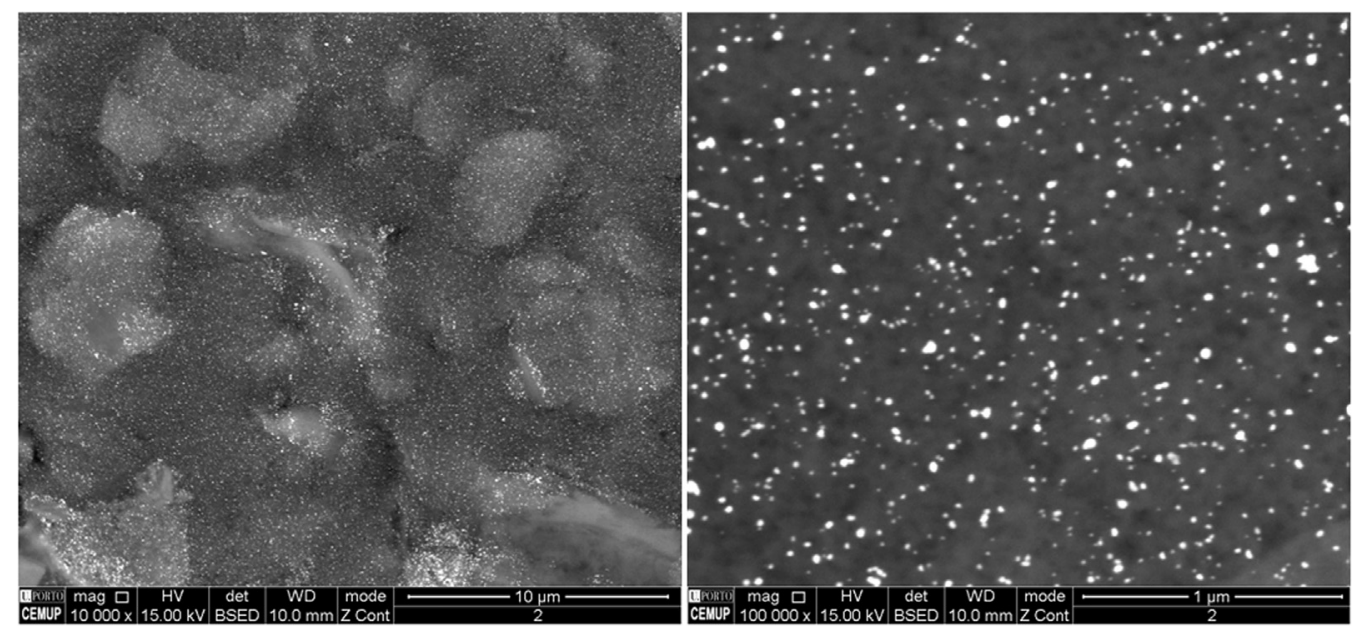

Fig. 1. SEM images of a gold nanoparticle-coated screen-printed carbon electrode.

hydrogen formed during the deposition process. The resulting gold nanoparticle-coated SPCEs were then rinsed with water and dried. The size of the gold nanoparticles obtained using this procedure is $32 \pm 10$ nm (Fig. 1).

\subsubsection{Immunosensor for the detection of Ara $h 1$}

In the optimized procedure (Fig. 2) the gold nanoparticle-coated SPCE (SPCE-nAu) was rinsed with $0.1 \mathrm{M}$ Tris- $\mathrm{HNO}_{3} \mathrm{pH} 7.2$ buffer, (1) coated with $10 \mu \mathrm{l}$ of a monoclonal anti-Ara h $12 \mathrm{C} 12$ antibody solution $(25 \mu \mathrm{g} / \mathrm{ml})$, and left to incubate overnight at $4{ }^{\circ} \mathrm{C}$. After incubation the electrode was washed with a $0.1 \mathrm{M}$ Tris- $\mathrm{HNO}_{3} \mathrm{pH}$ 7.2 buffer. Free surface sites were (2) blocked with a $\beta$-casein solution $\left(40 \mu \mathrm{l}, 2 \%\right.$ in $0.1 \mathrm{M}$ Tris- $\left.\mathrm{HNO}_{3} \mathrm{pH} 7.2\right)$ during $30 \mathrm{~min}$. After washing with the $0.1 \mathrm{M}$ Tris- $\mathrm{HNO}_{3} \mathrm{pH} 7.2$ buffer, (3) $40 \mu \mathrm{l}$ of a Ara h 1 standard solution or a food sample extract were placed on the SPCE-nAu for $60 \mathrm{~min}$ followed by a washing step with the $0.1 \mathrm{M}$ Tris- $-\mathrm{HNO}_{3} \mathrm{pH}$ 7.2 buffer. Then, the immunosensor was (4) incubated with $40 \mu \mathrm{l}$ of a previously prepared (60 min before use) mixture of biotinylated monoclonal anti-Ara h $12 \mathrm{~F} 7$ antibody and S-AP (final concentrations: $1: 10,000$ and $2 \times 10^{-10} \mathrm{M}$, respectively) for $120 \mathrm{~min}$ and subsequently washed with a $0.1 \mathrm{M}$ Tris- $\mathrm{HNO}_{3} \mathrm{pH} 9.8$ buffer containing $\mathrm{Mg}\left(\mathrm{NO}_{3}\right)_{2}\left(2 \times 10^{-2} \mathrm{M}\right)$. The enzymatic reaction was carried out (5) by placing $40 \mu \mathrm{l}$ of a solution containing 3 -IP $\left(1.0 \times 10^{-3} \mathrm{M}\right)$ and silver nitrate $\left(4.0 \times 10^{-4} \mathrm{M}\right)$ on the immunosensor's surface. In this step AP hydrolyzes 3-IP resulting in an indoxyl intermediate that reduces the silver ions in solution to metallic silver $\left(\mathrm{Ag}^{0}\right)$ and indigo blue (I). After $20 \mathrm{~min}$, (6) a linear sweep voltammogram was recorded from $-0.02 \mathrm{~V}$ to $+0.4 \mathrm{~V}$, at a scan rate of $50 \mathrm{mV} / \mathrm{s}$, to obtain the electrochemical stripping current of the enzymatically deposited silver. Analyses were always performed in triplicate and electrochemical measurements were carried out at room temperature.

\subsection{Statistical analysis}

Data are reported as average \pm standard deviation of triplicate assays. One-way ANOVA data analysis was carried out, as well as Student's $t$ tests to discriminate between any two groups under consideration. All analyses were carried out with Microsoft Excel Software (Microsoft Office Excel 2003, Microsoft Corp.).

\section{Results and discussion}

\subsection{Immunosensing strategy}

To develop this sandwich immunoassay, monoclonal antibodies were chosen because they are very specific for a single epitope of a certain protein. Their use usually shows advantages in assay

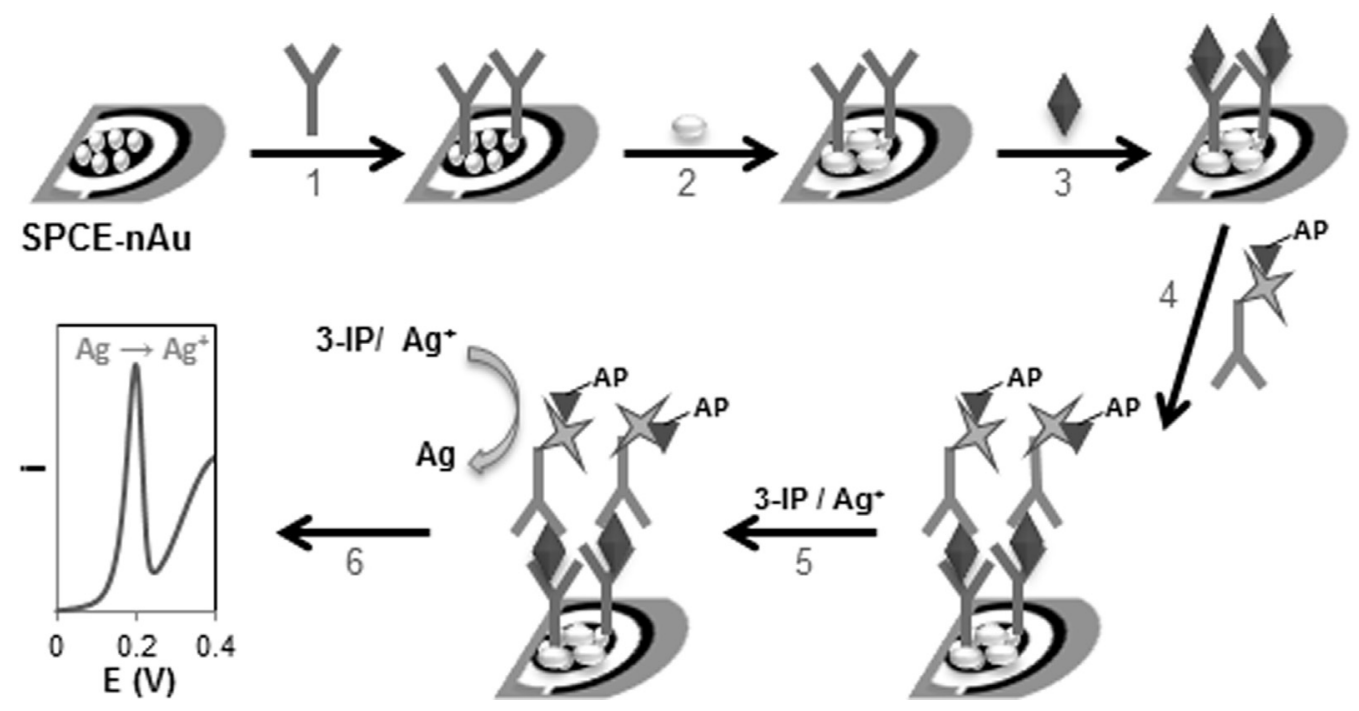

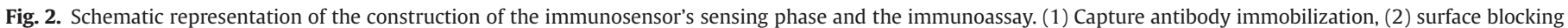

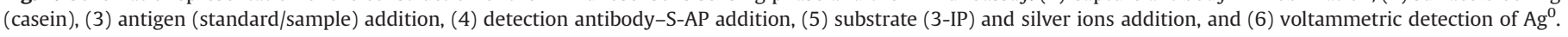


performance (reduction of nonspecific binding and cross-reactions) compared with polyclonal antibodies which, in turn, target a total protein extract. Therefore, it is expected that monoclonal antibodies allow the development of a more sensitive and selective immunosensor for the quantification of allergen trace levels in complex foods (Alves et al., in press).

In the first phase of the immunoassay development, the gold nanoparticle-modified SPCEs were coated with the capture antibody and left to incubate overnight at $4{ }^{\circ} \mathrm{C}$.

After that, the electrode surface was washed with $0.1 \mathrm{M}$ Tris$\mathrm{HNO}_{3} \mathrm{pH} 7.2$ buffer and free surface sites were blocked with a $\beta$ casein solution ( $2 \%$ in $0.1 \mathrm{M}$ Tris- $\mathrm{HNO}_{3} \mathrm{pH} 7.2$ ) during 30 min. After rinsing with $0.1 \mathrm{M}$ Tris- $\mathrm{HNO}_{3} \mathrm{pH} 7.2$ buffer, a solution containing Ara h 1 was applied on the electrode during $60 \mathrm{~min}$. After a new washing step, the immunosensor was incubated with the detection antibody, for $60 \mathrm{~min}$. After rinsing again, S-AP $\left(2 \times 10^{-10} \mathrm{M}\right)$ was added for $60 \mathrm{~min}$ and subsequently washed with a $0.1 \mathrm{M}$ Tris pH 9.8 buffer containing $\mathrm{Mg}\left(\mathrm{NO}_{3}\right)_{2}\left(2 \times 10^{-2} \mathrm{M}\right)$. The enzymatic reaction was carried out, during $20 \mathrm{~min}$, after placing a solution containing 3-IP $\left(1.0 \times 10^{-3} \mathrm{M}\right)$ and silver nitrate $\left(4.0 \times 10^{-4} \mathrm{M}\right)$ on the immunosensor surface.

In order to select the optimum concentrations of both the capture and detection antibodies a standard solution of Ara $\mathrm{h} 1$ $(700 \mathrm{ng} / \mathrm{ml})$ was used. First, for a fixed concentration of capture antibody $(25 \mu \mathrm{g} / \mathrm{ml})$, five different dilutions of detection antibody were tested $(1: 500,1: 1000,1: 5000,1: 10,000$ and 1:15,000). The obtained results can be observed in Fig. $3 \mathrm{~A}$.

The first three dilutions $(1: 500,1: 1000$, and 1:5000) resulted in the highest peak current intensities $\left(i_{\mathrm{p}}\right)$, however, the respective $i_{\mathrm{p}}$ values of the blank assays were significantly higher $(p<0.05)$ than those obtained with the $1: 10,000$ dilution. Although the $i_{\mathrm{p}}$ obtained in the presence of Ara h 1 was slightly lower, the low blank signals are analytically preferable, because they allow lower detection limits. Therefore, the 1:10,000 dilution was selected to proceed the studies. Subsequently, for a fixed detection antibody dilution $(1: 10,000)$, different concentrations of capture antibody were tested $(5,10,25,50$ and $100 \mu \mathrm{g} / \mathrm{ml})$ (Fig. 3B).

As shown, coating the electrode surface with a capture antibody solution of $25 \mu \mathrm{g} / \mathrm{ml}$ provided the best results: a significantly higher $(p<0.05)$ peak current intensity in the presence of the allergen and, simultaneously, low blank signals. Concentrations higher than $25 \mu \mathrm{g} / \mathrm{ml}$ originate lower analytical signals probably due to an excessive amount of adsorbed antibody that may block the antibody-antigen binding sites.

After selecting the capture antibody concentration $(25 \mu \mathrm{g} / \mathrm{ml})$ and the detection antibody dilution $(1: 10,000)$, different assay

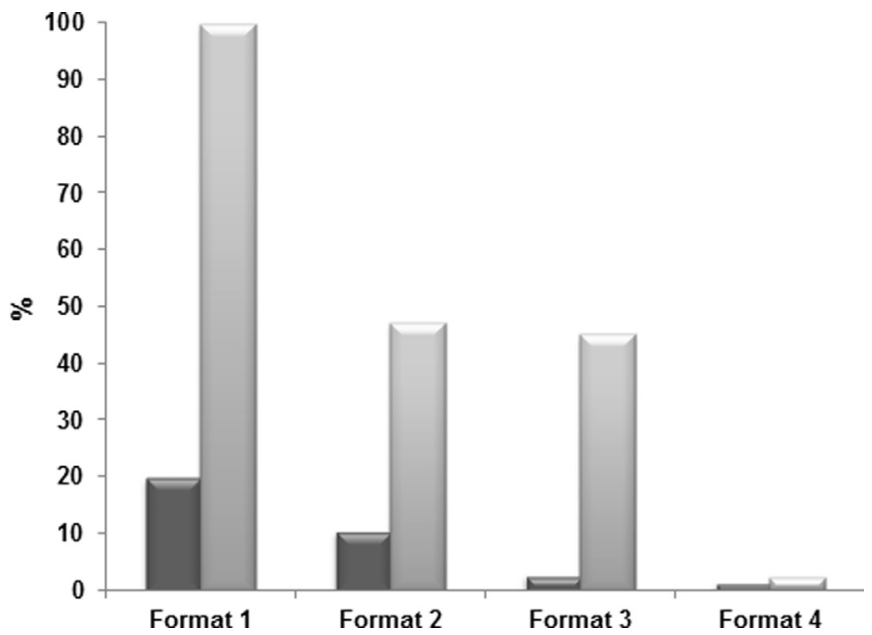

Fig 4. Comparison of peak current intensities (data presented in relative percentages, $n=3)$ of 4 assay formats. Dark grey bars: blank assays. Light grey bars: Ara $h$ $1(700 \mathrm{ng} / \mathrm{ml})$. Experimental conditions for all assays: capture antibody $(25 \mu \mathrm{g} / \mathrm{ml})$; $\beta$-casein (2\%); detection antibody (1:10,000); S-AP $\left(2 \times 10^{-10} \mathrm{M}\right)$; 3-IP $\left(1.0 \times 10^{-3}\right.$ $\mathrm{M})$ and silver nitrate $\left(4.0 \times 10^{-4} \mathrm{M}\right)$. Differences between assays: (1) the addition of immunoreagents was performed in separate steps; (2) antigen and detection antibody were previously mixed; (3) detection antibody and S-AP were previously mixed; and (4) antigen, detection antibody and S-AP were previously mixed.

formats were studied in order to reduce the steps and/or the total time of the immunoassay. Three different strategies were tested and compared with the previously described assay (Format 1): Format 2 - mixture of antigen and detection antibody; Format 3 mixture of detection antibody and S-AP; and Format 4 - mixture of antigen, detection antibody and S-AP. The obtained results are shown in Fig. 4. As can be observed, assay Format 1, in which the immunoreagents were added separately, provided the highest $i_{\mathrm{p}}$ values (for both the blanks and in the presence of Ara $h$ 1). Loss of signal is evident in the other studied assay formats which is probably due to steric hindrance when different reagents are mixed before being placed on the sensor's surface. However, Format 3 presented very interesting results: although the signal for the allergen was reduced by $\sim 50 \%$, the $i_{\mathrm{p}}$ for the blank assays also decreased significantly: about $85 \%$ when compared with Format 1. Therefore, Format 3 was chosen for the subsequent studies, with the advantage of reducing one of the steps of the immunoassay.

Further studies were performed in order to increase the $i_{\mathrm{p}}$. For this purpose, the solution containing the detection antibody and S-AP (final concentrations: $1: 10,000$ and $2 \times 10^{-10} \mathrm{M}$ ) was
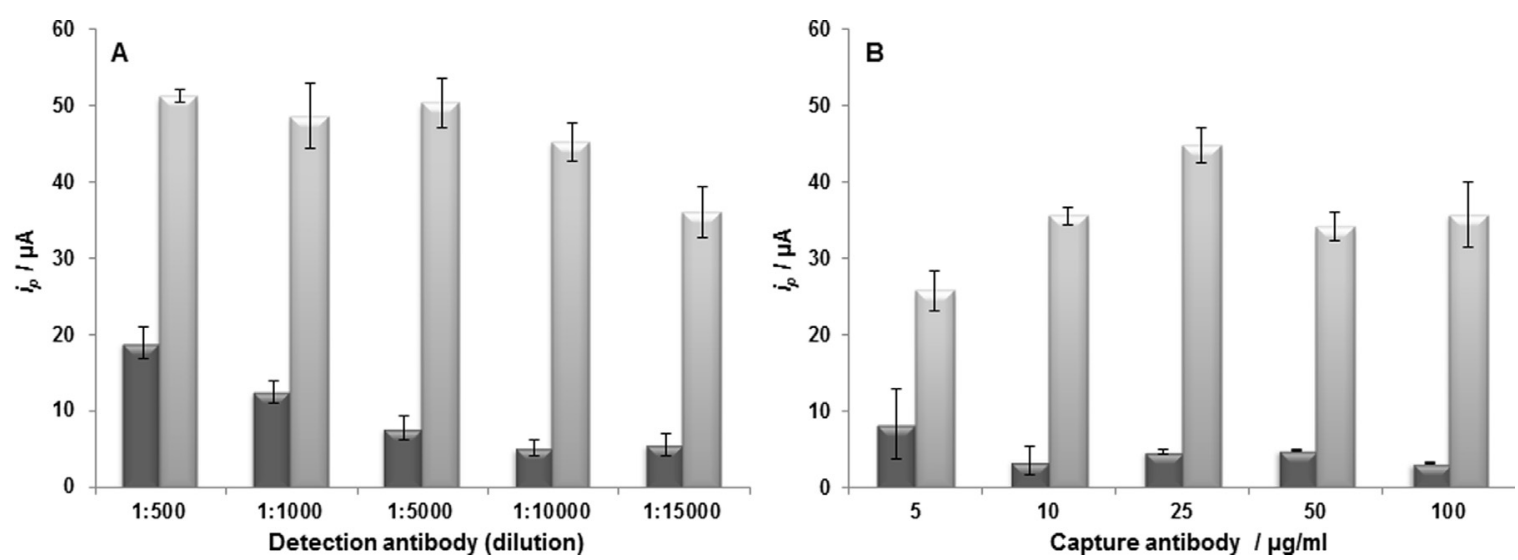

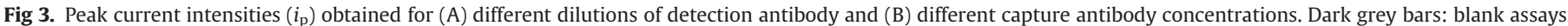

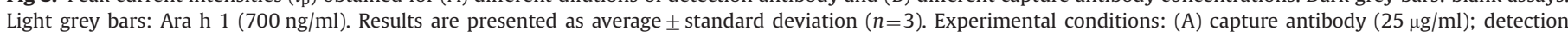

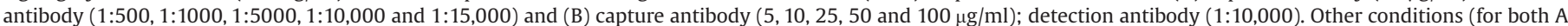
and B): $\beta$-casein (2\%); S-AP $\left(2 \times 10^{-10} \mathrm{M}\right)$; 3 -IP $\left(1.0 \times 10^{-3} \mathrm{M}\right)$ and silver nitrate $\left(4.0 \times 10^{-4} \mathrm{M}\right)$. 


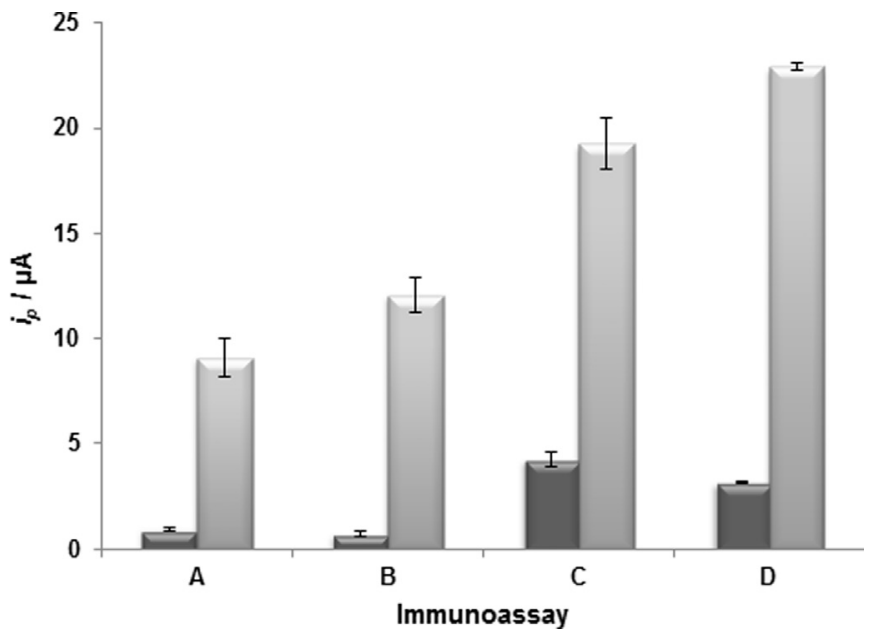

Fig 5. Peak current intensities $\left(i_{\mathrm{p}}\right)$ obtained in four different immunoassays based on assay format 3. Dark grey bars: blank assays. Light grey bars: Ara h 1 (700 ng/ $\mathrm{ml})$. Results are presented as average \pm standard deviation $(n=3)$. Experimental conditions for all assays: capture antibody $(25 \mu \mathrm{g} / \mathrm{ml}) ; \beta$-casein $(2 \%)$; mixture of detection antibody and S-AP (final concentrations: $1: 10,000$ and $2 \times 10^{-10} \mathrm{M}$, respectively); 3-IP $\left(1.0 \times 10^{-3} \mathrm{M}\right)$ and silver nitrate $\left(4.0 \times 10^{-4} \mathrm{M}\right)$. Differences between assays: (A) the mixture of detection antibody and S-AP was prepared $5 \mathrm{~min}$ before use and left to react $60 \mathrm{~min}$ on the sensor; (B) the mixture was prepared $60 \mathrm{~min}$ before use and left to react $60 \mathrm{~min}$ on the sensor; (C) the mixture was prepared $5 \mathrm{~min}$ before use and left to react $120 \mathrm{~min}$ on the sensor; and (D) the mixture was prepared 60 min before use and left to react 120 min on the sensor.

prepared $5 \mathrm{~min}$ ( $\mathrm{A}$ and $\mathrm{C}$ ) and $60 \mathrm{~min}$ (B and $\mathrm{D}$ ) before use. Furthermore, both mixtures were left to react during $60 \mathrm{~min}$ (A and $\mathrm{B}$ ) and $120 \mathrm{~min}$ ( $\mathrm{C}$ and $\mathrm{D}$ ) on the sensor's surface. The differences between the results were clear and are depicted in Fig. 5. According to the obtained data, a significant $(p<0.05)$ increase of the $i_{\mathrm{p}}$ was achieved when preparing the mixture $60 \mathrm{~min}$ before use and increasing the incubation time to $120 \mathrm{~min}$ (assay D). Moreover, in this assay (D) significantly $(p<0.05)$ better precisions compared to the A, B and C assay formats were obtained. Regarding the blank signals, still very low $i_{\mathrm{p}}$ values were obtained $(\sim 2.5 \mu \mathrm{A})$, and therefore, this assay procedure was selected for the Ara h 1 immunosensor.

Additional studies with this final assay procedure were carried out using a higher amount of Ara h $1(2000 \mathrm{ng} / \mathrm{ml})$ to verify the adequacy of the capture and detection antibody concentrations for this assay. Again, different concentrations (10, 25, 50 and $100 \mu \mathrm{g} /$ $\mathrm{ml}$ ) of capture antibody, and distinct dilutions (1:1000, 1:5000, $1: 10,000,1: 20,000$ and $1: 30,000)$ of detection antibody were tested. As expected, the best results were, once more, obtained with the same concentrations selected before: $25 \mu \mathrm{g} / \mathrm{ml}$ of capture antibody and a 1:10,000 dilution of the detection antibody.

\subsection{Method validation}

The precision of the methodology was evaluated in terms of repeatability and reproducibility using a $700 \mathrm{ng} / \mathrm{ml}$ Ara h 1 solution. The repeatability was evaluated by performing five successive inter-electrodic measurements using separate immunosensors and the reproducibility was assessed through 5 inter-day evaluations. Relative standard deviations were $2.9 \%$ and $8.7 \%$, respectively, showing that the immunosensor provides precise results.

For calibration purposes, Ara h 1 standard solutions with increasing concentrations $(25,50,100,250,500,1000,2000,3000$, and $4000 \mathrm{ng} /$ $\mathrm{ml}$ ) were prepared and analysed with the immunosensor. A linear semi-logarithmic relationship between Ara h 1 concentration and $i_{\mathrm{p}}$ was obtained between 25 and $2000 \mathrm{ng} / \mathrm{ml}\left(i_{\mathrm{p}}(\mu \mathrm{A})=(17.89 \pm 1.66) \times\right.$ $\log [C](\mathrm{ng} / \mathrm{ml})-(24.34 \pm 1.81), r=0.997)$ and signal saturation was observed for concentrations higher than $2000 \mathrm{ng} / \mathrm{ml}$. Examples of

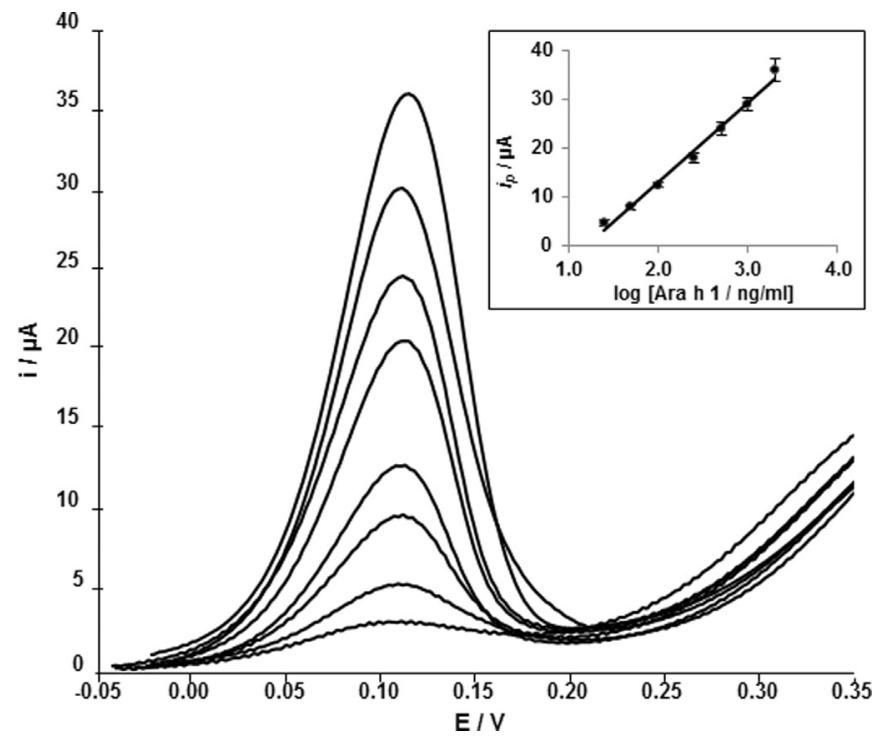

Fig 6. Examples of voltammograms in the linear range (blank: first voltammogram from the bottom; [Ara h 1] (ng/ml): 25, 50, 100, 250, 500, 1000 and 2000). Inset: Calibration plot. Experimental conditions: capture antibody $(25 \mu \mathrm{g} / \mathrm{ml}) ; \beta$-casein (2\%); mixture of detection antibody and S-AP (final concentrations: 1:10,000 and $2 \times 10^{-10} \mathrm{M}$, respectively); 3-IP $\left(1.0 \times 10^{-3} \mathrm{M}\right)$ and silver nitrate $\left(4.0 \times 10^{-4} \mathrm{M}\right)$.

voltammograms in the linear range and the calibration plot are shown in Fig. 6. The limits of detection (LOD) and the quantification (LOQ) were calculated from the calibration plots using the following equations: $\mathrm{LOD}=3 \mathrm{~s} / \mathrm{m}$ and $\mathrm{LOQ}=10 \mathrm{~s} / \mathrm{m}$, where "s" is the standard deviation of the intercept and " $\mathrm{m}$ " is the slope of the calibration plot. The LOD and LOQ values obtained were 3.8 and $12.6 \mathrm{ng} / \mathrm{ml}$, respectively.

Independently of the efficiency of $\beta$-casein as blocking agent, the presence of several other proteins in the food samples can lead to non-specific adsorptions on the sensor's surface and impair the detection of Ara h 1 with the developed immunosensor. It was also essential to evaluate if both antibodies bound specifically to the Ara $\mathrm{h} 1$ protein present in the samples. For this purpose several samples that could present cross-reactivity and/or interfere in the response of the immunosensor were tested. Cookies (containing, among other ingredients, listed in Section 2, whey powder and egg), cashews, almonds, walnuts, pistachios, peas, lentils, and lupines, all gave negative results i.e., no significant differences ( $p>0.05$ ) when compared with the blank assays).

Because of the absence of a reference material, pure peanut beans were extracted and Ara h 1 was quantified. The obtained value of $12.76 \pm 1.65 \mathrm{mg} / \mathrm{g}$ of peanut $(n=3)$ is in good agreement with the concentration of this allergen in peanut described in the literature (Pomés et al., 2006). For recovery experiments, a cookie extract was spiked with four increasing amounts of the purified standard Ara h 1 (final concentrations: 50, 250, 500 and $1000 \mathrm{ng} /$ $\mathrm{ml}$ ). Recoveries of $98.9 \%, 98.7 \%, 97.7 \%$, and $96.6 \%$, respectively, were obtained which indicated that no matrix effect was observed when compared with the calibration plot constructed in buffer solution. Furthermore, cookie samples were spiked with increasing amounts of peanut (final concentrations: $0.1 \%, 0.3 \%$, and $1.5 \%$ ) and the results showed that even the lowest amount of peanut $(0.1 \%)$ could easily be detected with this immunosensor.

The developed immunosensor was also used to detect Ara h 1 presence in chocolate samples with and without peanut. The chocolate sample without peanut gave a negative result (no significant differences $(p>0.05)$ when compared with the blank assays). On the other hand, in the chocolate sample containing peanut as ingredient, $8.7 \mu \mathrm{g}$ of Ara $\mathrm{h} 1 / \mathrm{g}$ of chocolate were detected. 
In comparison with other published immunosensors for the analysis of Ara h 1 (Huang et al., 2008; Pollet et al., 2011), the major drawback of the developed immunosensor is the analysis time (3 h 50 min); Huang et al. (2008) and Pollet et al. (2011) reported analysis times of $5 \mathrm{~min}$ and $20 \mathrm{~min}$, respectively. However, this drawback is largely overcome by the wider calibration range (25-2000 ng/ml) and much lower LOD (3.8 ng/ml) obtained in this work when compared to the ones obtained by Huang et al. (2008) (20-240 ng/ml, <20 ng/ml) and Pollet et al. (2011) (1002000 ng/ml, 90 ng/ml). Furthermore, Huang et al. (2008) did not report the analysis of samples; therefore the utility of the developed sensor is not fully proven.

Regarding a DNA biosensor using EIS detection developed by Sun et al. (2012) for the analysis of Ara h 1 in peanut milk, once again the analysis time of the developed sensor in this work seems to be the biggest drawback since they reported an analysis time of $1 \mathrm{~h} 30 \mathrm{~min}$. Comparison of the results with this method is complicated because only DNA concentrations are reported (linear range: $10^{-10}-10^{-15} \mathrm{M}$, LOD: $0.35 \times 10^{-15} \mathrm{M}$ ), which cannot be directly related to Ara h 1 concentration.

\section{Conclusions}

In this work, gold nanoparticle-coated screen-printed carbon electrodes were used to develop a two-monoclonal antibody sandwich-type electrochemical immunosensor for Ara h 1 (a major peanut allergen) detection. Several variables of the immunosensing strategy were optimized, namely antibody concentrations, the number of steps to perform the analysis, and the assay time.

Precision and accuracy studies indicate that the proposed methodology is reproducible, presents a good repeatability, and provides accurate results. The limit of detection achieved with this immunosensor was very low $(3.8 \mathrm{ng} / \mathrm{ml})$ comparatively to other biosensors described in the literature. The immunosensor was successfully applied to Ara h 1 detection in complex food matrices, such as cookies and chocolate.

\section{Acknowledgements}

Rita C. Alves is grateful to Fundação para a Ciência e a Tecnologia (FCT) for a post-doctoral research grant (SFRH/BPD/
68883/2010), financed by POPH-QREN-Tipologia 4.1-Formação Avançada, subsidized by Fundo Social Europeu and Ministério da Ciência, Tecnologia e Ensino Superior. This work received financial support from the European Union (FEDER funds through COMPETE) and National Funds (FCT) through project Pest-C/EQB/ LA0006/2013. The work also received financial support from the European Union (FEDER funds) under the framework of QREN through Project NORTE-07-0124-FEDER-000069.

\section{References}

Alves, R.C., Barroso, M.F., González-García, M.B., Oliveira, M.B.P.P., Delerue-Matos, C. 2014. Crit. Rev. Food Sci. Nutr., in press, 10.1080/10408398.2013.831026. Berin, M.C., Sicherer, S., 2011. Curr. Opin. Immunol. 23, 794-800.

Besler, M., Kasel, U., Wichmann, G., 2002. Int. Symp. Food Allergy 4, 1-18.

Chafen, J.J.S., Newberry, S.J., Riedl, M.A., Bravata, D.M., Maglione, M., Suttorp, M.J., Sundaram, V., Paige, N.M., Towfigh, A., Hulley, B.J., Shekelle, P.G., 2010. J. Am. Med. Assoc. 303, 1848-1856.

Chruszcz, M., Maleki, S.J., Majorek, K.A., Demas, M., Bublin, M., Solberg, R., Hurlburt, B.K., Ruan, S., Mattison, C.P., Breiteneder, H., Minor, W., 2011. J. Biol. Chem. 286 39318-39327

de Leon, M.P., Rolland, J.M., O’Hehir, R.E., 2007. Expert Rev. Mol. Med. 9, 1-18.

Fanjul-Bolado, P., Hernández-Santos, D., González-García, M.B., Costa-García, A 2007. Anal. Chem. 79, 5272-5277.

Huang, Y., Bell, M.C., Suni, I.I., 2008. Anal. Chem. 80, 9157-9161.

Khodoun, M., Strait, R., Orekov, T., Hogan, S., Karasuyama, H., Herbert, D.R., Köhl, J. Finkelman, F.D., 2009. J. Allergy Clin. Immunol. 123, 342-351.

Leung, A., Kamat, D., 2008. In: Chesterton, C.M. (Ed.), Food Allergies: New Research. Nova Science Publishers Inc., New York, pp. 91-120.

Martínez-Paredes, G., González-García, M.B., Costa-García, A., 2009a. Electrochim. Acta 54, 4801-4808.

Martínez-Paredes, G., González-García, M.B., Costa-García, A., 2009b. Electroanalysis $21,925-930$

Monaci, L., Visconti, A., 2009. TrAC - Trends Anal. Chem. 28, 581-591.

Monaci, L, Visconti, A, 2010. Trends Food Sci. Technol. 21, 272-283.

Pele, M., Brohee, M., Anklam, E., van Hengel, A.J., 2007. J. Food Addit. Contam. 24 1334-1344.

Pollet, J., Delport, F., Janssen, K.P., Tran, D.T., Wouters, J., Verbiest, T., Lammertyn, J. 2011. Talanta 83, 1436-1441.

Pomés, A., Butts, C.L., Chapman, M.D., 2006. Clin. Exp. Allergy 36, 824-830.

Singh, R., Sharma, P.P., Baltus, R.E., Suni, I.I., 2010. Sens. Actuators B - Chem. 145, 98-103.

Słowianek, M., Majak, I., 2011. Food Sci. 75, 39-44.

Sun, X., Guan, L., Shan, X., Zhang, Y., Li, Z., 2012. J. Agric. Food Chem. 60, 10979 10984.

Taylor, S.L., Nordlee, J.A., Niemann, L.M., Lambrecht, D.M., 2009. Anal. Bioanal. Chem. 395, 83-92.

Tran, D.T., Knez, K., Janssen, K.P., Pollet, J., Spasic, D., Lammertyn, J., 2013. Biosens. Bioelectron. 43, 245-251. 